\title{
neofilolog
}

Czasopismo Polskiego Towarzystwa Neofilologicznego

ISSN 1429-2173, 2021, NR 56/2, 363-367

http://dx.doi.org/10.14746/n.2021.56.2.13

http://poltowneo.org/

Maciej Smuk

Uniwersytet Warszawski https://orcid.org/0000-0002-0911-9046

m.smuk@uw.edu.pl

\section{Elżbieta Gajewska, Magdalena Sowa, Joanna Kic-Drgas Filologia wobec wyzwań komunikacji specjalistycznej. Od współpracy z biznesem po kształcenie nauczycieli}

Poznań: Wydawnictwo Naukowe UAM , 2020, 238 s.

\begin{abstract}
Keywords: specialist communication, teacher training, philology/language studies, curricula
\end{abstract}

Słowa kluczowe: komunikacja specjalistyczna, kształcenie nauczycieli, filologia/studia językowe, programy studiów

M onografia autorstwa E. Gajewskiej, M. Sowy i J. Kic-Drgas Filologia wobec wyzwań komunikacji specjalistycznej. Od wspótpracy z biznesem po kształcenie nauczycieli (Poznań: Wydawnictwo Naukowe UAM, 2020) dotyczy kształcenia filologicznego w Polsce widzianego przez pryzmat glottodydaktyki specjalistycznej. Oryginalność tej publikacji polega na tym, że - z jednej strony jej Autorki mówią o przygotowaniu studentów do komunikacji specjalistycznej w języku obcym, z drugiej zaś - poświęcają uwagę przygotowaniu przyszłych nauczycieli języków obcych do nauczania języka specjalistycznego. Te dwa ujęcia uzupełniają się, stanowiąc jednocześnie filary monografii.

Recenzowana pozycja z pewnością zainteresuje osoby odpowiedzialne za programy studiów na studiach językowych (filologie, lingwistyki stosowane itp.) i nauczycieli praktycznej nauki języka, zwłaszcza nauczycieli różnych odmian specjalistycznych. Powinni po nią też sięgnąć studenci realizujący zajęcia 
przygotowujące do wykonywania zawodu nauczyciela. W szerszym ujęciu książka jest skierowana do decydentów zaangażowanych w diagnozowanie i projektowanie kierunków rozwoju polskich uczelni, także z punktu widzenia ich tzw. trzeciej misji, czyli konieczności nawiązywania współpracy ze środowiskiem zewnętrznym, tj. przedsiębiorstwami, jednostkami administracji państwowej, instytucjami społecznymi, placówkami oświatowymi i kulturalnymi itd. Publikacja powinna też trafić do przedstawicieli środowisk pracy, a więc pracodawców, pracowników działów personalnych czy osób odpowiedzialnych w firmach za szkolenia.

M onografia składa się z trzech rozdziałów - ich struktura i zakres tematyczny sprawiają, że można je czytać niezależnie (to duży atut), co nie zmienia faktu, że stanowią one spójną całość. Części zasadnicze uzupełniają wstęp i podsumowanie, spis bibliografii, wykazy skrótów i objaśnień stosowanych w publikacji, jak również obszerne załączniki, które zawierają informacje o komponentach glottodydaktyki specjalistycznej na studiach językowych w Polsce oraz dane wynikające z przeglądu programów studiów dokonanego przez Autorki (warto dodać, że szczegółowe informacje zawarte w aneksach mogą stanowić same w sobie przedmiot analizy i nie obligują czytelnika do odwoływania się do tekstu głównego).

W dalszej części recenzji zwrócę uwagę na najważniejsze atuty poszczególnych rozdziałów.

W rozdziale pierwszym Filologia a otoczenie gospodarcze Autorki - bardzo klarowanie i przystępnie - przedstawiają możliwe związki między studiami językowymi a otoczeniem zewnętrznym. Przypominają też (sekcja 1.1.3 - Filolog: rynek pracy i nast.), że znajomość języków obcych znajduje się na liście priorytetów pracodawców, przewyższając swoją popularnością tzw. wiedzę branżową. Ta wysoka pozycja w rankingu dowodzi, że pracodawcy zrozumieli, iż czas niezbędny do opanowania języka obcego jest - zazwyczaj - nieporównywalnie dłuższy od czasu niezbędnego do zdobycia umiejętności związanych z daną branżą czy stanowiskiem pracy. Tradycyjne kursy językowe, organizowane w wielu przedsiębiorstwach w formie jednego lub dwóch spotkań w tygodniu, mogą więc nie spełniać podstawowych choćby oczekiwań pracodawców wobec kompetencji językowych pracowników biorących w nich udział (częstokroć całymi latami!). Poza danymi dotyczącymi oczekiwań pracodawców ważną częścią tego rozdziału są wszystkie treści na temat form współpracy między uczelniami a otoczeniem gospodarczym sensu largo. Ztego punktu widzenia inspirujące są przykłady konkretnych praktyk, które Autorki przytaczają w kilku miejscach (np. 1.2.1, 1.2.3) lub je omawiają. W sekcji Przykłady współpracy kierunków filologicznych z sektorem gospodarczym (nr 1.2.4), tematem są: kształcenie językowo-przedmiotowe (CLIL), włączanie 
w programy studiów językowych przedmiotów związanych ze środowiskiem pracy, tworzenie kierunków hybrydowych (np. język w biznesie, lingwistyka w komunikacji specjalistycznej), realizowanie projektów badawczych z podmiotami zewnętrznymi, prowadzenie zajęć przez osoby związane ze środowiskiem gospodarczym, organizowanie grup zajęć w ścisłej współpracy z konkretnymi przedsiębiorstwami lub współtworzenie tzw. studiów dualnych.

Rozdziały drugi i trzeci, chociaż pod względem treści się różnią, to łączy je wspólny mianownik - Autorki analizują programy studiów językowych w zakresie sześciu języków - angielskiego, francuskiego, hiszpańskiego, niemieckiego, rosyjskiego i włoskiego - na 22 polskich uniwersytetach. Uzupełnieniem tych rozdziałów, a zarazem elementem, który powinien towarzyszyć ich lekturze, są aneksy, które zawierają szczegółowe zestawienia odnośnie do różnych aspektów nauczania języków specjalistycznych na studiach językowych. Jak wspomniałem wcześniej, same w sobie stanowią one bezcenne źródło danych o filologiach obcych na polskich uczelniach.

W rozdziale drugim pt. Filolog a znajomość specjalistycznych odmian języka obcego Autorki porównują ofertę programów studiów językowych pod kątem przygotowania studentów do komunikacji specjalistycznej ${ }^{1}$. Różnorodność stosowanego na poszczególnych kierunkach nazewnictwa - język fachowy, język w świecie pracy, językowe warsztaty zawodowe, gatunki użytkowe w biznesie, języki specjalistyczne w przekładzie, dyskurs specjalistyczny itd. - odzwierciedla różnorodność podejść do zagadnienia. Przegląd dokonany przez Autorki dowodzi, jak rozległy jest zakres tematyczny języków specjalistycznych nauczanych na studiach językowych - od ogólnych, jak np. język medycyny, po wąskie, np. język w obsłudze ruchu granicznego, język samorządu terytorialnego i NGO. Analiza ilościowa ujawnia też pewną (niepokojącą) tendencję: częstokroć za synonim języka specjalistycznego uznawany jest język biznesu (ekonomiczny, gospodarczy...) i tylko jemu poświęca się miejsce w programach studiów.

W świetle danych przedstawionych w rozdziale drugim szczególnie trafne wydają się zalecenia sformułowane przez Autorki w sekcji Przygotowanie specjalistyczne filologów: konkluzje i wnioski (nr 2.5). Rekomendują one w nauczaniu odmian specjalistycznych m.in. stosowanie zasad dydaktyki do celów zawodowych (która nie jest tożsama z dydaktyką dla potrzeb zawodowych) (Gajewska, Sowa: 2014: 46-47) oraz położenie nacisku na rozwijanie umiejętności strategicznych, które umożliwią adeptom samodzielnie rozwijanie kompetencji językowych w obrębie danej dyscypliny (danych dyscyplin) i w nowych, dynamicznie zmieniających się kontekstach.

${ }^{1}$ Przedmiotem analizy są programy studiów rozpoczynające się roku akademickim 2019/2020. 
Rozdział trzeci, Filolog jako nauczyciel języka obcego specjalistycznego, to - zgodnie z moim stanem wiedzy - najbardziej nowatorska część publikacji w tym sensie, że nie istnieją w Polsce źródła, które tak przekrojowo omawiałyby problematykę kształcenia nauczycieli na studiach językowych, patrząc na nią przez pryzmat ich przygotowania do nauczania języka specjalistycznego. M oją uwagę zwróciły szczególnie dwie sekcje teoretyczne. W sekcji Nauczyciel języka specjalistycznego: osoba do (zbyt?) wielu zadań (nr 3.2) Autorki sporządzają listę zadań nauczycieli języków specjalistycznych, dając asumpt do refleksji na temat praktycznych implikacji na tym polu. W sekcji Programowanie kształcenia w zakresie JOS: potencjalne trudności (nr 3.4) mierzą się zaś z wyzwaniami planowania zajęć o tej specyfice. Ich bardzo realna i trafna analiza powinna zainteresować - w wymiarze praktycznym - autorów programów zajęć językowych i sylabusów przedmiotów.

Wnioski wynikające z analizy programów studiów językowych na 22 polskich uniwersytetach, dotąd nieprezentowane w piśmiennictwie fachowym, dowodzą niedostatecznej obecności lub wręcz nieobecności glottodydaktyki specjalistycznej w kształceniu nauczycieli. Jest to zaskakujące nie tylko ze względu na określony popyt na rynku pracy, lecz także dlatego, że kształcenie nauczycieli to jeden z trzonów kształcenia filologicznego - powinno więc ono podlegać systematycznej ewolucji, uwzględniając bieżące uwarunkowania ekonomiczne i społeczne. Zdanie zawarte w końcowej części sekcji Kształcenie nauczycieli języków obcych specjalistycznych - perspektywy (nr 3.6) skupia w sobie w jakimś sensie całokształt wyzwań: „Wprowadzenie do programów kształcenia nauczycieli języków obcych modułów poświęconych glottodydaktyce specjalistycznej pozwoliłoby w większym stopniu uwzględniać realia nauczania języków obcych we współczesnym świecie [...]" (s. 146). Warto dodać, że przykłady praktyk zamieszczone w tym rozdziale (np. Tabela 10) stanowią wystarczającą inspirację do refleksji o potencjalnych rozwiązaniach.

Mówiąc o zaletach monografii Filologia wobec wyzwań komunikacji specjalistycznej..., nie można też nie wspomnieć o istotnych - także ilościowo - treściach teoretycznych, które pozwalają uchwycić całościowo specyfikę nauczania języków specjalistycznych. Zjednej strony - są to autorskie wywody i odwołania intertekstowe na temat specyficznych cech tego typu komunikacji, np. uwagi o różnicach między terminami 'tekst specjalistyczny', 'dyskurs specjalistyczny', 'gatunki specjalistyczne' oraz 'styl i rejestr' (w sekcjach od 2.3.1 do 2.3.5), czy też rozważania o granicach kompetencji filologów/nauczycieli języków specjalistycznych (w sekcjach 1.1, 3.1 i 3.2); z drugiej strony - praktyk znajdzie w niej szereg rekomendacji i wskazówek dotyczących planowania: po pierwsze - kursów języków specjalistycznych, a po drugie - kursów kształcących nauczycieli języków specjalistycznych (np. w sekcjach 1.2.2, 1.2.3, 2.1.3, 2.2.5, 2.3.6, 3.3, 3.4 lub 3.6). 
Przedstawione wyżej oceny i uwagi cząstkowe pozwalają mi określić recenzowaną monografię mianem kompleksowego kompendium na temat cech glottodydaktyki specjalistycznej, które łączy w sobie spójny naukowy wywód, bogatą analizę danych empirycznych i zbiór praktycznych zaleceń. Uważam, że monografia autorstwa E. Gajewskiej, M. Sowy i J. Kic-Drgas jest niezwykle cenna społecznie. Wypełnia ona lukę, jeśli chodzi o analizę obecnego stanu i scenariusze (koniecznych) ewolucji studiów językowych w Polsce. Stanowi również doskonałe uzupełnienie poprzedniej pracy o glottodydaktyce specjalistycznej dwóch z trzech Autorek (Gajewska, Sowa, 2014).

\section{Bibliografia}

Gajewska E., Sowa M . (2014), LSP, FOS, Fachsprache... Dydaktyka języków specjalistycznych. Lublin: Werset.

Received: 03.03 .2021

Revised: 11.03 .2021 